\title{
Determining the Importance of Competency and Person-Job Fit for the Job Performance of Service SMEs Employees in Malaysia
}

\author{
Sethela June ${ }^{1}$, Yeoh Khar Kheng ${ }^{1} \&$ Rosli Mahmood ${ }^{1}$ \\ ${ }^{1}$ College of Business, School of Business Management, Universiti Utara Malaysia, Sintok, Kedah, Malaysia \\ Correspondence: Sethela June, College of Business, School of Business Management, Universiti Utara Malaysia, \\ Sintok, Kedah, Malaysia. Tel: 60-4-928-4000 ext 2408. E-mail: sethela@uum.edu.my; sethelajune@yahoo.com
}

\author{
Received: April 25, 2013 Accepted: May 27, 2013 Online Published: August 1, 2013 \\ doi:10.5539/ass.v9n10p114 URL: http://dx.doi.org/10.5539/ass.v9n10p114
}

\begin{abstract}
The small and medium enterprises (SMEs) have contributed to the economic growth and competitiveness of many countries. However, as the SMEs continue to grow as an important entity in many economies including Malaysia, many factors have dampened such progress. While previous studies had focused on its macro perspective in terms of firm level and industry level performance, this study attempted to address the basic issue of SMEs employees in terms of their job performance. This study is underpinned by the theory of job performance and further supported by the theory of congruence. The main objective of this research is to investigate on the relationship that may exist between three variables comprised of competency, person-job fit and the employees' job performance in the context of service SMEs. Using a quantitative method, a sample of 324 responses was collected using a mail survey from 1500 distributed questionnaires. Results show significant relationships between competency, person-job fit and the job performance of employees. Conclusions and implications of the study were discussed.
\end{abstract}

Keywords: SMEs, service SMEs, job performance, competency, person-job fit, job performance, Malaysia

\section{Introduction}

One of the important factors that can contribute to organizational performance is employee job performance. Employees who performed well will not only help organizations to meet strategic goals. They are also playing an important role in marinating organization competitiveness (Dessler, 2011). As such, it is important to identify the factors that can affect the job performance of employees both in large enterprises and in SMEs. The SME sector plays a vital role in both the developed and developing countries in terms of economic growth and promoting competitiveness (Caniels \& Romijn, 2005). In general, 50\% GDP of most developed countries comes from this sector (Kefela, 2010) while it contributed approximately $30 \%$ to $60 \%$ of the GDP of the East Asian region with an estimated $70 \%$ of employment (Hall, 2002). As such, many researchers are interested to examine the various obstacles that hinder their progress (Alasadi \& Abdelrahim, 2008).

SMEs are a major sector in Malaysia. Of all the 523,132 business establishments that were involved in a Census on Establishments and Enterprises in year 2005, it was found that the majority of the companies in Malaysia is made up of SMEs. The data obtained showed that there were almost 99.2\% or 518,996 SMEs in Malaysia (Department of Statistics, 2006). Thus, the significance of carrying out this study in the context of SMEs is evidenced in view of how important the sector is to the economic development of Malaysia. There are three sectors of SMEs in Malaysia comprised of manufacturing, service and agriculture (Saleh \& Ndubisi, 2006).

In terms of sectoral size, $86.5 \%$ of the SMEs in Malaysia is made up of service SMEs. This figure has placed the service SMEs as the largest sector of the SMEs establishments in Malaysia (Department of Statistics, 2006). There are 2.2 million people employed in the service SMEsas compared to the manufacturing sector (740,438 employees) and agriculture sector (131,130 employees) (Aris, 2007). However, labor productivity tends to be higher among the employees of larger enterprises than those of the smaller firms. In Malaysia, only RM0.05 million value-added and RM0.13 million outputs per employee were generated by SME employees as compared to those from the larger enterprises which recorded approximately RM0.1 million of value-added and RM0.32 million outputs per employee (SME Annual Report, 2007). This condition had been invoked by the prevailing problems of lack of skills and abilities among the employees of SMEs as compared to those from the larger enterprises (Reed, Walsh, \& Grice, 2001). Additionally, the labor productivity between those working in the service SMEs and those in the 
manufacturing SMEs have not been in proportion with the number of employment. This is because even though there is highest employment in the service SMEs as compared to the manufacturing SMEs, the labor productivity contribution from those working in the manufacturing SMEs is higher at RM64089 while those from the service SMEs is only at RM 47151 (SME Annual Report, 2007). This condition suggested that employees in the service SMEs are less skillful, and thus has affected their job performance (Saleh \& Ndubisi, 2006).

\section{Gaps in the Literature}

Past researches have shown that employees in a service setting can only be effective in performing their job if they possessed the right competency. Hence, in order to deliver effective services, employees need to be skillful and trained (Zeithaml, Parasuraman \& Berry, 1990). Some examples of competencies that are necessary for service employees consist of friendliness, concern, insight, communication and adaptive were noted (Hartline \& Ferrell, 1996). Besides that, it is well known among the behaviorist theorists to view the importance the fit between employees and their job (Kristof-Brown, Zimmerman \& Johnson, 2005). Moreover, the effective completion of a job can be realized where there is a manifestation of person-job fit (Edwards, 1991) and evidenced has shown that the productivity and commitment of employees can be influenced by how much fit exist between a person and the job (Rousseau \& McLean Parks, 1992).

Despite of evidences from the past studies on the relationship between competency and job performance lack of evidence exist in the context of Malaysia. Moreover of those studies in Malaysia that looked at the competency variable, (e.g. Deros, Yusof \& Salleh, 2006; Ahmad, Ramayah, Wilson \& Kummerow, 2010); Azmi, 2010) the focused issues were either related to the entrepreneurs' or the public sector employees. Similarly, studies on person-job fit were limited to those that were done in abroad (e.g. Caldwell \& O'Reilly, 1990; Carless, 2005); Hecht \& Alle, 2003; Erdogan \& Bauer, 2005; Behery, 2009). Given the importance of both employees' job performance and the service SMEs in Malaysia, the aim of this research is to ascertain whether employee competency and person-job fit is significantly related to the employee's job performance. It is hoped that this study will add on the dearth of research concerning employees working in the SMEs sector specifically of the service SMEs in Malaysia.

\section{Theoretical Background}

Resource-based view (RBV) acknowledged that firms would be able to sustain its competitive advantage through its human resources (employees) Barney (1991). This is achievable when the employees are able to achieve a good level of job performance. Theory of performance refers to performance as what a person needs to carry out and do well when hired by an organization (Campbell, McCloy, Oppler \& Sager, 1993). Based on the theory, three factors comprised of declarative knowledge, procedural and skills knowledge and motivation can influence employee job performance. A declarative knowledge includes knowledge about facts, principles, goals and self- knowledge in association with a given task. On the other hand, cognitive skills, psychomotor skills, physical skills, self-management skills, and interpersonal skills formed the procedural knowledge and skills. As for the motivations element, it is seen as the result of combining three behavioral choices that are the choice to perform, the level of effort, and the persistence of the effort (Campbell et al., 1993). Hence, the descriptions of declarative knowledge and procedural knowledge and skills are related closely to employee competency. This is based on the notion that when competency exists, an individual possessed the knowledge about the basic task requirements and the necessary abilities that reflect the motive, trait, skill, aspect of one's self-image or social role, or a body of knowledge that an individual uses in carrying out a task (Boyatzis, 1982). According to Barrett's (1978) Congruency theory, person-job fit occurred when the individual preferences matched the requirements of the job (which entails the knowledge, skills and abilities) (Lawrence, 2004). The existence of congruence of both the person and the job will lead to a motivational outcome (Barrett, 1978; Edwards, 1991). Hence, the research framework (as shown in Figure 1) was underpinned by the theory of performance and the theory of Congruence. 


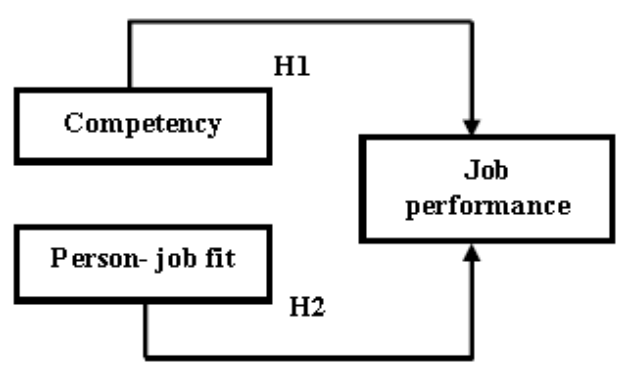

Figure 1. Research framework

\subsection{Job Performance}

There are various descriptions of employee job performance. Bohlander, Snell and Sherman (2001) suggested employee job performance is related to employees having the knowledge about their work goals and able to meet the expectations of the job target or achieving the work standard established by their organization. Alternatively, job performance has also been described as the outcome of two facets that employees may possess comprised of abilities (natural) and skills (acquired) which can be a good source of motivation for better job performance (Sarmiento \& Beale, 2007).

Since performance is, what a person needs to carry out and do well when hired by organization thus only measurable actions could be regarded as performance (Campbell et al., 1993). It is important in any service setting, that employees are able to deliver excellent service and this could be done should the employees possessed the right skills (Zeithaml et al., 1990). Besides, the existence of fit between an employee and the job has proven to be important in many organizational behavior research (Kristof-Brown et al., 2005) and effective deliverances of a job has long been associated with the existence of job fit (Edwards, 1991). Therefore, investigating on the predictors of job performance such as competency and person-job fit is necessary in line with the nature of the work of those working in the service SMEs.

\subsection{Relationship between Competency and Job Performance}

McClelland concluded that when predicting job performance, people must be evaluated based on their competencies (McClelland, 1973). Competency is a form of ability and the fundamental characteristics of a person, which is important for effective job performance (Boyatzis, 1982). Thus, when individuals possessed a competency, it goes to show that an individual is capable of fulfilling task requirements. Job performance and competency had found to be positively related to each other (Linders, 2001) and high level of individual and organizational performance has been contributed by employee competency (Armstrong, 2006). In an attempt to show that competencies can produce effective work, (Kagaari \& Munene, 2007) conducted a study among the engineering lecturers at Kyambogo University. The result revealed that lecturers with relevant competencies were able to deliver effective work outcome. Similarly, an investigation was carried out among the nurses in Taiwan revealed that there is a significant relationship between competency and job performance (Tzeng, 2004). Additionally, Hashim (2008) carried out a study in Malaysia discovered that in order for the managers to perform well, it is necessary for them to possess various competencies such as communications, management and job knowledge. Most researches on competencies conducted on small firms were looking at firm competencies rather than on employees' competencies. In addition, the majority of the past studies focused on managers as the unit of analysis. This has therefore created a gap concerning the need to conduct studies on non-managerial employees of an organization. As such, the first hypothesis is:

Hypothesis 1: There is a significant relationship between competency and job performance among the employees of the service SMEs.

\subsection{Relationship between Person-Job Fit and Job Performance}

One of the common conceptualization of fit concepts is the supplementary fit versus a complementary fit approach (Muchinsky \& Manohan, 1987). A supplementary fit is characterized by the similarity that may exist between a person and the organization environment or with other employees in the organization (personally-person fit) (Sekiguchi, 2003). Conversely, when the characteristics of an individual can complement and create completeness in an organization, a complementary fit is said to occur. Given that supplementary fit has to do with the match between a person and the organization environment rather than the job (Muchinsky \& Manohan, 1987), it cannot be used to analyze person-job fit (Sekiguchi, 2004). As such, it is common to find the concept of complementary fit 
in the past researches on person-job fit (Kristof-Brown et al., 2005). The effect of person-job fit on employee job performance has yet to receive much attention of researchers, which has resulted in limited research found (Mosley, 2002). Furthermore, the concrete influence of person-job fit on employee job performance in those past researches have yet to be strongly supported given the many variations of the findings (Edwards, 1991). There were mixed results obtained from past researches on the relationship between person-job fit and job performance (Greguras \& Diefendorff, 2009). Therefore, it can be concluded that past studies have yet to come to an agreement on the influence of person-job fit towards the job performance of employees (Conte, Rizzutto \& Steiner, 1999). As such, the second hypothesis is:

Hypothesis 2: There is a significant relationship between person-job fit and job performance among the employees of the service SMEs.

\section{Methodology}

In order to carry out this study, a quantitative research was employed using mail survey approach. Data was collected using a questionnaire that was designed using a Likert scale of 7-point. Job performance was adapted from Williams and Anderson (1991) and after testing for initial reliability; only 4 items from the original 6 items were retained. On the other hand, the instrument for competency was adapted from Bajunaid (2008) and contained 24 items. As for person-job fit it, the measurement was adapted from Lauver and Kristof-Brown (2001) and contained 6 items altogether.

\subsection{Population and Sampling}

A systematic random sampling technique was chosen in which a sample is chosen by selecting a random starting point and then picking every $\mathrm{K}^{\text {th }}$ element in succession from the sampling frame (Hair, Black, Babin, Anderson \& Tatham, 2006). The central bank of Malaysia defined service SMEs as those firms with employees of between 5 to 50 employees (Bank Negara Malaysia, 2005). The directory of SMEs (SME Business Directory, 2011) was used as a sampling frame in order to know that number of service SMEs firms exist in Malaysia. Through the directory, there are 5527 service enterprises registered in Malaysia. The total elements of the entire population using the given definition by the central bank of Malaysia for a minimum number of employees in a service SMEs, it was estimated to be at 27635 employees (5527 firms x 5 employees). Thus, the minimum required sample size with a population of $\mathrm{N}=27635$ are 379 employees (Krejcie \& Morgan, 1970).

\section{Results}

In order to collect the data, 1500 questionnaires were mailed to the respondents. Although there were 324 employees responded, only 300 responses can be used for analysis. Thus, the response rate for this study is $20 \%$ in line with the prevailing response rate of mail survey done in Malaysia that commonly falls in the $10 \%$ to $20 \%$ range (Ramayah, Yan \& Sulaiman, 2005). Data from 5 respondents were omitted through the Mahalanobis $\mathrm{D}^{2}$ scores outlier test. Finally, data from 295 respondents were used for further analysis. In order to test consistency, a reliability test was carried on the measurements used in this study. Table 1 shows the result of the reliability test during the pre - test study and after factor analyses were carried out. The result of the tests suggested that the measurements used were reliable given the Cronbach's alpha value had all exceeded the threshold value of 0.7 (Nunnally, 1978; Nunnally, 1983).

Table 1. Reliability statistic

\begin{tabular}{lll}
\hline Variable & Cronbach's Alpha (pretest) & Cronbach's Alpha (after factor analysis) \\
\hline Job performance & 0.87 & 0.87 \\
Competency & 0.90 & 0.94 \\
Person-job fit & 0.91 & 0.88 \\
\hline
\end{tabular}

Factor analysis was utilized to test the construct validity of the measurements. The suitability of using factor analysis has to be confirmed prior to its use for construct validity testing. This can be done by measuring the sample adequacy using the Kaiser-Meyer-Olkin (KMO) and to conduct a Barttlet's Test of Sphericity. The likeliness for factorability is known when the value of KMO is greater than 0.6 (Coakes, Steed \& Ong, 2009) and the Bartlett's test of sphericity figure is large and significant $(\mathrm{p}<0.5)$ (Hair et al., 2006). The result of KMO measure and Barttlet's Test of Sphericity for all the variables comprised of job performance, competency and person-job fit satisfies the threshold value of greater than 0.6 (Coakes et al., 2009) and significant at $\mathrm{p}<0.05$ 
(Hair et al., 2006). Based on this, factorability is considered as possible.

Table 2 shows the result of factor analysis of job performance. In this study, an item will be chosen to identify with factor when the loadings are greater than 0.3 as suggested by Hair et al. (2006). A threshold value of 0.3 is considered to be moderately high (Kline, 1994). Based on the analysis, all four questions used to measure job performance are loaded onto a single factor with eigenvalue of more than 1.0. The single factor extracted $71.13 \%$ of the total variance in response.

Table 2. Summary of factor loading for job performance

\begin{tabular}{lc}
\multicolumn{1}{c}{ Question } & Component \\
\hline JP1 completes assigned duties & 0.868 \\
JP2 fulfil responsibilities according to job descriptions & 0.878 \\
JP3 able to perform as expected & 0.853 \\
JP4 meet the formal performance standards & 0.770 \\
Eigenvalues & 2.845 \\
Percentage of variance explained $=71.13 \%$ & \\
KMO $=0.814$ & \\
Bartlett's Test of Sphericity: & \\
Approx. Chi-Square $=562.505$ & \\
df $=6$ & \\
Sig $=.000$ & \\
\hline
\end{tabular}

Table 3 shows the factor analysis conducted on 24 items for the competency variable and 6 items for the person-job fit variable. The result of the initial factor analysis found many items with high cross loadings for competency variable. Hence, the decision was made to drop those items with cross loadings that is higher than 0.32 as suggested by (Tabachnick \& Fidell, 2001) and this is done based on several rounds of principal component analysis. Eventually only 15 items of the total 24 items on competency were retained while none of the person-job fit items were dropped. Hence, there were 15 items extracted from Factor 1 namely Competency and 6 items extracted from Factor 2, namely Person-job fit. The eigenvalue showed that the first factor (Competency) explained $38.3 \%$ of the variance and the second factor (Person-job fit) contributed $19.9 \%$ of the variance. Thus, the two factors explained $58.2 \%$ of the variance.

Table 3. Summary of factor loading for competency and person-job fit

Rotated Component Matrix ${ }^{\mathrm{a}}$

\section{Component}

1 2

C1 teamwork \& cooperation

C2 flexibility

C4 computer literacy

C5 conceptual thinking

C11 customer service orientation

C13 directiveness

C14 team leadership

C16 self control

C17 organization commitment 
C19 interpersonal understanding

C21 personal planning \& org skills

C22 written communication

C23 information seeking

C24 achievement orientation

PJ1 goof fit bet job and what being looked for

PJ2 attributes looked for fulfilled by present job

$\mathrm{PJ} 3$ job gives everything that is expected

PJ4 good match between job demand and skills

PJ5 abilities \& training fit with job requirement

PJ6 personal abilities \& education match with job

demand

Eigenvalue

Percentage of variance explained $38.3 \%$

$19.9 \%$

$\mathrm{KMO}=.939$

Bartlett's Test of Sphericity

Approx. Chi-Square $=3915.334$

$\mathrm{df}=210$

Sig $=.000$

Results from the analysis of profile indicate that $53.6 \%$ of the respondents are made up of female employees while male employees made up the balance $46.4 \%$ of the respondents. In terms of age of the respondents, $46.2 \%$ of the respondents belong to those aged between 19 to 30 years old, which forms the majority while the second largest group of the respondents came from those aged between 31 to 40 years that amounted to $30.5 \%$. The racial distribution shows that $58.0 \%$ of the respondents are Chinese while the Malays and Indians made up the $20.3 \%$ and $14.9 \%$ of the respondents respectively while the rest of them are the Bumiputera from Sabah and Sarawak. The job profile of the respondents shows that they are involved in various business sectors. As for employment attachment, three groups dominate the job profile of the respondents. The majority of the respondents are working in the education sector (14.9\%) while $14.6 \%$ of them are the employees of restaurants and those working in the professional service business made up $14.2 \%$ of the total respondents. On the other hand, the tenure of service shows that only $11.2 \%$ of the respondents had worked less than 1 year in the firm that they are currently serving. Analysis of the educational background of the respondents shows that the majority of the respondents had completed tertiary education ranging from diploma $(21.7 \%)$, bachelor degree $(30.5 \%)$ to postgraduate $(9.8 \%)$.

The inter-correlations of all the variables in this study are shown in Table 4. The significance level of this study is set at 5\% which is a generally accepted in social sciences research (Sekaran \& Bougie, 2009). The table shows that competency and job performance is significantly related $(\mathrm{r}=0.552, \mathrm{p}<0.01)$. The same outcome is also found for the next variable in which person-job fit is significantly related to the job performance of employees ( $\mathrm{r}$ $=0.478, \mathrm{p}<0.01)$. However, based on the result, the influence of competency on the job performance of employees is stronger (given the higher ' $r$ ' value) than the influence of person-job fit.

Table 4. Correlation matrix of competency, person-job fit and job performance

\begin{tabular}{llll}
\hline & 1 & 2 & 3 \\
\hline Job performance (1) & 1.000 & & \\
Com_Mean (2) & $.552^{* *}$ & 1.000 & \\
PJFit_mean (2) & $.478^{* *}$ & $.526^{* *}$ & 1.000 \\
\hline
\end{tabular}

**. Correlation is significant at the 0.01 level (2-tailed). 
Table 5. Multiple regression of competency, person job fit and job performance

\begin{tabular}{lccccccc}
\hline Independent & \multicolumn{7}{c}{ Job Performance (Dependent Variable) } \\
Variables & Beta & Std Error & Std Beta & $\mathrm{t}$ & $\mathrm{Sig}$ & Tolerance & VIF \\
\hline (Constant) & 2.409 & .262 & & 9.195 & .000 & & \\
Person-job Fit & .245 & .052 & .259 & 4.689 & .000 & .723 & 1.382 \\
Competency & .363 & .048 & .415 & 7.509 & .002 & .723 & 1.382 \\
$\mathrm{R}$ & 0.594 & & & & & & \\
$\mathrm{R}^{2}$ & 0.353 & & & & & \\
$\mathrm{~F}$ & 79.749 & & & & & \\
Sig & 0.000 & & & & & \\
\hline
\end{tabular}

Table 5 presents the result of the multiple regression analysis. The value of $\mathrm{R}^{2}$ reveals that $35.3 \%$ of the variance in job performance can be significantly explained by the two constructs understudied namely competency and person-job fit. The Beta value of 0.415 for competency and 0.259 for person-job fit indicates that the job performance of employees could be enhanced when competency of employees is increased while those who are fit for their job may experience an elevation in their job performance. Consequently, Hypotheses 1 and 2 are supported. The result from Table 5 also shows a VIF value that is less than 10 which suggested that the model was free from the multicollinearity problem (Hair et al., 2006). Furthermore, the inter-correlations value of less than 0.7 (considered as moderately low) as shown in Table 4 has similarly suggested low chances for the occurrence of multicollinearity among the independent variables (Nunnally \& Bernstein, 1994).

\section{Discussions and Implications}

This study attempts to examine the relationship between competency, person-job fit and the job performance among the employees of the service SMEs in Malaysia. Based on the Pearson analysis, it was found that both competency and person-job fit is significantly related to the job performance of employees in the service SMEs. Similar findings from past researches on competency with the present study suggested that employees can only perform well in their job if they possessed the competency to do so which reflects (McClelland, 1973). Furthermore, given the significant relationship between competency and job performance, it can be concluded that in order to improve the performance of employees' job performance, serious attention must be given to issues related to their competencies. This is because, the anticipated job performance can only be achieved when the competency possessed by the employees match with the desired competency to perform a job (Agut \& Grau, 2002). Additionally, this study suggested that it is necessary for firms to use competency based performance measure (Moore, Cheng \& Dainty, 2002). The use of competency based assessment will allow managers to know the level of job performance among the employees, and hence able to adopt competence-based training as a technique to improve their job performance.

In addition to this, since person-job fit can influence employees' job performance, thus it can also affect the choice of job that they would like to do. Generally, it is well known that people tend to prefer job that has the element of meaningfulness as well as those that can satisfy their internal and their external needs. In other words, when person-job fit occurs, employees have the inclination to perform better in their job as they are more willing to put forth their energy in fulfilling their duties that they enjoy doing. The fact that person-job fit is being associated with employees having the right skills and abilities to fulfil job demands, it is more likely for them to be motivated to perform at a higher level and to remain on the job when fit existed (Hecht \& Allen, 2003; Kristof-Brown et al., 2005; June \& Mahmood, 2011). Therefore the findings from this study further suggested that in order to motivate employees to meet the required job performance, it is necessary for person-job fit to exist as described by the Field Theory (Lewin, 1951). The theory explains that the interaction that occurs between the employees and their job environment will produce good working behavior. Hence, when a good person-job fit exists, employees will be able to exert greater effort to perform better. Employee effort plays a crucial role in their job performance. The idea that employees are more willing to exert their effort in carrying out their duties and responsibilities are critical to the success of any service based firms. This is because in any service setting, the level of contact between the employees with the customers is generally high. As such employees who are fit to the job that they are doing will tend to deliver higher quality of service. Due to this condition, it is suggested that the hiring of employees in the service SMEs must be based on person-job fit in order to achieve the anticipated job performance. 
Given that this study able to bring forward the importance of competency in employee job performance in the service SMEs, it is suggested that future research to consider developing a model of competencies specifically tailored to those employees working in the service sector SMEs. Key-decision makers can use this as a diagnostic tool in identifying the strengths and weaknesses of employees so that a more robust training program can be developed and to meet the needs of the organizations. Additionally, future research may also consider replicating this study in the other context of SMEs in Malaysia in order for comparison to be made across the sector that will promote better understanding of the factor that can affect the job performances of employees in the SMEs sector in Malaysia. Likewise, this may allow a more concerted effort to be carried out to enhance the level of productivity among the employees of SMEs, which will help in the growth of the sector further.

\section{References}

Agut, S., \& Grau, R. (2002). Managerial competency needs and training requests: the case of the Spanish tourist industry. Human Resource Development Quarterly, 13(1), 31-51. http://dx.doi.org/10.1002/hrdq.1012

Ahmad, N. H., Ramayah, T., Wilson, C., \& Kummerow. (2010). Is entrepreneurial competency and business success relationship contingent upon business environment? A study of Malaysian SMEs. International Journal of Entrepreneurial Behavior \& Research, 16(3), 182-203. http://dx.doi.org/10.1108/13552551011042780

Alasadi, R., \& Abdelrahim, A. (2008). Analysis of small business performance in Syria. Education, Business and Society: Contemporary Middle Eastern Issues, 1(1), 50-62. http://dx.doi.org/10.1108/17537980810861510

Aris, N. M. (2007). SMEs: building blocks for economic growth. Journal of the Department of Statistics Malaysia, 1, 1-14.

Armstrong, M. (2006). A Hand Book of Human Resource Management Practices (10th ed.). London: Kogan Page Ltd.

Azmi, I. A. G. (2010). Competency-based human resource practices in Malaysian public sector organizations. African Journal of Business Management, 4(2), 235-241.

Bajunaid, M. M. (2008). The effectiveness of cooperative education programmes for developing students' awareness of the importance of generic competencies. (Doctoral dissertation). Retrieved from http://theses.gla.ac.uk/489/01/2008bajunaidphd.pdf

Bank Negara Malaysia. (2005). Small and medium enterprise (SME) annual report 2005. Kuala Lumpur: Bank Negara Malaysia.

Barney, J. (1991). Firm resources sustained competitive advantage. Journal of Management, 17, 99-121. http://dx.doi.org/10.1177/014920639101700108

Barrett, G. V. (1978). Task design, individual attributes, work satisfaction and productivity. In A. R. Negandhi, \& B. Wilpert (Eds.), Work Organization Research: Americana and European Perspectives (pp. 261-278). Kent, $\mathrm{OH}$ : The Kent State University Press.

Behery, M. H. (2009). Person/organization job-fitting and affective commitment to the organization: Perspectives from the UAE. Cross Cultural Management: An International Journal, 16(2), 179-196. http://dx.doi.org/10.1108/13527600910953928

Bohlander, G., Snell, S., \& Sherman, A. (2001). Managing human resources. Australia: South-Western College Publishing.

Boyatzis, R. E. (1982). The competent manager. New York: John Wiley \& Sons.

Caldwell D. F., \& O'Reilly, C. A. III. (1990). Measuring person-job fit with a profile comparison process. Journal of Applied Psychology, 75, 648-657. http://dx.doi.org/10.1037/0021-9010.75.6.648

Campbell, J. P., McCloy, R. A., Oppler, S. H., \& Sager, C. E. (1993). A theory of performance. In E. Schmitt, W. C. Borman, \& Associates (Eds.), Personnel selection in organizations (pp. 35-70). San Francisco: Jossey-Bass.

Caniels, M. C. J., \& Romijn, H. A. (2005). What works, and why, in business services provision for SME: insights from evolutionary theory. Managing Service Quality, 15(6), 591-608. http://dx.doi.org/10.1108/09604520510634041

Carless, S. A. (2005). Person-job fit versus person-organization fit as predictors of organizational attraction and job acceptance intentions: A longitudinal study. Journal of Occupational and Organizational Psychology, 78, 411-429. http://dx.doi.org/10.1348/096317905X25995

Coakes, S. J., Steed, L., \& Ong, C. (2009). SPSS 16.0 for windows: Analysis without anguish. Australia: John 
Wiley and Sons.

Conte, J. M., Rizzutto, T. E., \& Steiner, D. D. (1999). A construct-oriented analysis of individual level $\begin{array}{lllll}\text { polychronicity. Journal of } & \text { Managerial }\end{array}$ http://dx.doi.org/10.1108/02683949910263837

Department of Statistics. (2006). Census of establishments and enterprises 2005, preliminary report - profile of small and medium enterprises.

Deros, B. M., Yusof, S. M., \& Salleh, A. M. (2006). A benchmarking implementation framework for automotive manufacturing SMEs. Benchmarking: An International Journal, 13(4), 396-430. http://dx.doi.org/10.1108/14635770610676272

Dessler, G. (2011). Human Resource management (12th ed.). Prentice-Hall, USA.

Edwards, J. R. (1991). Person-job fit: A conceptual integration, literature review, and methodological critique. In C. L. Cooper, \& I. T. Robertson (Eds.), International review of industrial and organizational psychology, 6 (pp. 283-357). Chichester, UK: John Wiley \& Sons, Ltd.

Edwards, J. R. (2008). Person-environment fit in organizations: an assessment of theoretical progress. The Academy of Management Annals, 2(1), 167-230. http://dx.doi.org/10.1080/19416520802211503

Erdogan, B., \& Bauer, T. N. (2005). Enhancing Career Benefits of Employee Proactive Personality: The Role of Fit with Jobs and Organizations. Personnel Psychology, 58, 859-891. http://dx.doi.org/10.1111/j.1744-6570.2005.00772.x

Greguras, G. J., \& Diefendorff, J. M. (2009). Different fits satisfy different needs: linking person-environment fit to employee commitment and performance using self-determination theory. Journal of Applied Psychology, 94(2), 465-477. http://dx.doi.org/10.1037/a0014068

Hair, J. F., Black, W. C., Babin, B. J., Anderson, R. E., \& Tatham, R. L. (2006). Multivariate data analysis (6th ed.). New Jersey: Pearson Prentice Hall.

Hall, C. (2002). Profile of SMEs and SME issues in APEC 1999-2000. Mexico: APEC SME Ministerial Meeting.

Hartline, M. D., \& Ferrell, O. C. (1996). The management of customer-contact service employees: An empirical investigation. The Journal of Marketing, 60(4), 52-70. http://dx.doi.org/10.2307/1251901

Hashim, J. (2008). Competencies acquisition through self-directed learning among Malaysian managers. Journal of Workplace Learning, 20(4), 259-271. http://dx.doi.org/10.1108/13665620810871114

Hecht, T. D., \& Allen, N. J. (2003). Person-job fit on the dimension of polychronicity: Examining links with well-being and performance. Academy of Management Best Conference Paper.

June, S., \& Mahmood, R. (2011). The relationship between person-job fit and job performance: a study among the employees of the service SMEsin Malaysia. International Journal of Business, Humanities and Technology, 1(2), 95-105.

Kagaari, J. R. K., \& Munene, J. C. (2007). Engineering lecturers' competencies and organizational citizenship behavior (OCB) at Kyambogo University. Journal of European Industrial Training, 31(9), 706-726. http://dx.doi.org/10.1108/03090590710846675

Kefela, G. T. (2010). The service sector - high employment with low productivity growth prospect for emerging economies. Accountancy Business and the Public Interest, 9.

Kline, P. (1994). An easy guide to factor analysis. London: Routledge.

Krejcie, R., \& Morgan, D. (1970). Determining sample size for research activities. Educational and Psychological Measurement, 30, 607-610.

Kristof-Brown, A. L., Zimmerman, R. D., \& Johnson, E. C. (2005). Consequences of individuals' fit at work: A meta-analysis of person-job, person-organization, person-group, and person-supervisor fit. Personnel Psychology, 58(2), 281-342. http://dx.doi.org/10.1111/j.1744-6570.2005.00672.x

Lauver, K. J., \& Kristof-Brown, A. (2001). Distinguishing between employees' perceptions of person-job and person-organization fit. Journal of Vocational Behavior, 59, 454-470. http://dx.doi.org/10.1006/jvbe.2001.1807

Lawrence, A. D. (2004). Screening for Person-Job fit: Incremental validity of a congruence approach to assessment. (Doctoral dissertation). Retrieved from ProQuest Dissertations and Theses database.

Lewin, K. (1951). Field theory in social science: selected theoretical papers. Westport, CT: Greenwood Press.

Linders, J. R. (2001). Competency Assessment and Human Resource Management Performance of County Extension Chairs in Ohio. Journal of Agriculture Education, 24(4), 21-31. 
McClelland, D. C. (1973). Testing for Competence Rather Than for Intelligence. American Psychologist, 28 , 1-14. http://dx.doi.org/10.1037/h0034092

Moore, D., Cheng, M., \& Dainty, A. (2002). Competence, competency and competencies: performance assessment in organizations. Work Study, 51(6), 314-319. http://dx.doi.org/10.1108/00438020210441876

Mosley, D. C. (2002). The influence of person-job fit, person-organization fit, and self-efficacy perceptions on work attitudes, job performance and turnover. (Doctoral dissertation). Retrieved from ProQuest Dissertations and Theses database.

Muchinsky, P. M., \& Manohan, C. J. (1987). What is person-environment congruence? Supplementary versus complementary models of fit. Journal of Vocational Behavior, 31, 268-277. http://dx.doi.org/10.1016/0001-8791(87)90043-1

Nunnally, J. C. (1978). Psychometric theory (2nd ed.). New York: McGraw-Hill.

Nunnally, J. C. (1983). Psychometric theory. New York: McGraw-Hill.

Nunnally, J. C., \& Bernstein, I. H. (1994). Psychometric Theory. New York: McGraw-Hill.

Ramayah, T., Yan, L. C., \& Sulaiman, M. (2005). SME e-readiness in Malaysia: Implications for Planning and Implementation. Sasin Journal of Management, 11(1), 103-120.

Reed, F. M., Walsh, K., \& Grice, R. (2001). Supporting the information needs of small manufacturing firms. paper presented at 25th ISBA National Small Firms Policy and Research Conference, Competing Perspectives of Small Business and Entrepreneurship.

Rousseau, D. M., \& McLean Parks, J. (1992). The contracts of individuals and organizations. Research in Organizational Behavior, 15, 1-47.

Saleh, A. S., \& Ndubisi, N. O. (2006). SME development in Malaysia: Domestic and global challenges. University of Wollongong.

Sarmiento, R., \& Beale, J. (2007). Determinants of performance amongst shop-floor employees. Management Research News, 30(12), 915-927. http://dx.doi.org/10.1108/01409170710833349

Sekaran, U., \& Bougie, R. (2009). Research methods for business (5th ed.). West Sussex UK: John Wiley \& Sons, Inc.

Sekiguchi, T. (2003). The Role of person-organization fit and person-job fit in managers' hiring decision: the effects of work status and occupational characteristics of job openings. (Doctoral dissertation). Dissertation Abstracts International, 64 (8-A), 2978.

Sekiguchi, T. (2004). Person-organization fit and person-job fit in employee selection: A review of the literature. Osaka Keidai Ronshu, 54(6), 179-196.

SME Annual Report. (2007). Retrieved http://www.smeinfo.com.my/index.php?ch=2\&pg=286\&ac=727\&lang=en on 28 December 2008

SME Business Directory (2011). Retrieved March 17, 2011, from https://www.secure.smeinfo.com.my/directory/search.php

Tabachnick, B. G., \& Fidell, L. S. (2001). Using multivariate statistics (4th ed.). Needham Heights, MA: Allyn \& Bacon.

Tzeng, H. M. (2004). Nurses' self-assessment of their nursing competencies, job demands and job performance in the Taiwan hospital system. International Journal of Nursing Studies, 41, 487-496. http://dx.doi.org/10.1016/j.jpurstu.2003.12.002

Williams, L., \& Anderson, S. (1991). Job satisfaction and organizational commitment as predictors of organizational citizenship and in-role behaviors. Journal of Management, 17, 601-617. http://dx.doi.org/10.1177/014920639101700305

Zeithaml, V. A., Parasuraman, A., \& Berry, L. L. (1990). Delivering Quality Service: Balancing Customer Perceptions and Expectations. New York, NY: Free Press.

\section{Copyrights}

Copyright for this article is retained by the author(s), with first publication rights granted to the journal.

This is an open-access article distributed under the terms and conditions of the Creative Commons Attribution license (http://creativecommons.org/licenses/by/3.0/). 